\title{
The Relationship between Perceived Security Threats and Negative Descriptions of Armenians in Turkish Politics (1946-1960)
}

\author{
Türkay Salim Nefes (D) \\ Institute of Public Policy, Spanish National Research Council, Spain \\ Camlik cd. Cigdem sk. Mutlu ap. No: 7/5. 342812. Bahcelievler, Istanbul, Turkey. \\ Email: tnefes@gmail.com
}

\begin{abstract}
How do perceived threats influence politicians' attitudes towards religious minorities? Examining the Turkish parliamentary records between 1946 and 1960, this study suggests that perceived security threats significantly contribute to Turkish political parties' negative descriptions of Armenians. The research analyzes speeches about Armenians via a mixed-method content analysis. The findings demonstrate that (a) debate about security threats is a reliable predictor of the political parties' negative portrayals, and (b) members of the parliament justify their negative views by labeling Armenians as an enemy. The article concludes that perceived threats evoke negative speeches about Armenians in Turkish politics.
\end{abstract}

Keywords: group position theory; ethnic conflict; Turkey; parliamentary records; Turkish-Armenian relations

\section{Introduction and the Historical Background}

What are the bases of ethnic and religious prejudice? Under what circumstances do political parties encourage hostility towards minorities? Given that mainstream political parties often shape longlasting policies about minorities in the modern world, it is imperative to examine the factors associated with their hostile speeches. According to a very influential sociological perspective, group position theory (Blumer 1958; Bobo 1999; Olzak 1992), dominant groups' perceptions of threats to their prerogatives can explain their hostility towards minorities. This perspective focuses mainly on the developed world and emphasizes the size of minority populations and worsening economic conditions as important contributors to intergroup animosity. Because this perspective has limited analyses of the historical backgrounds of hostilities in the developing world, this study addresses these scholarly gaps by focusing on Turkish politics and accounting for historical influences on ethnoreligious hostility. It explores the role of perceived threats in negative descriptions of Armenians between 1946 and 1960.

Bringing together group position theory and scholarship on non-Muslim minorities in Turkey, this research proposes that perceived security threats significantly contribute to Turkish political parties' negative descriptions of Armenians. This advances the scholarship first by expanding the sociological literature through successfully applying group position theory to the field of TurkishArmenian relations. Second, the study develops group position theory by bringing evidence from macro-level party politics, using mixed methods, and accounting for the historical background of

\footnotetext{
(C) The Author(s), 2021. Published by Cambridge University Press on behalf of the Association for the Study of Nationalities. This is an Open Access article, distributed under the terms of the Creative Commons Attribution licence (http://creativecommons.org/licenses/by/4.0/), which permits unrestricted re-use, distribution, and reproduction in any medium, provided the original work is properly cited.
} 
the perceived threats in an underexplored context. Third, by using Turkish parliamentary proceedings, the research contributes to filling the gap of a systematic analysis of the perception of Armenians in Turkish politics. Last, using mixed-method content analysis is a novel and efficient strategy for group position theory as well as the scholarship on Turkish-Armenian relations.

In the Ottoman Empire between the fifteenth and twentieth centuries, the Armenian Gregorian community, along with the Jewish and Greek Orthodox minorities, lived under the millet system (Barkey 2008), which in the nineteenth century included other communities: Protestants in 1847 and the Orthodox Bulgarian Church in 1870 (Mylonas 2019, 869). The Ottoman rulers followed the Sunni version of Islam and classified non-Muslim groups into two main categories: polytheists and the "People of the Book," who believed in the Abrahamic religions. While polytheists did not receive any official recognition, the "People of the Book" were granted the dhimmi (protected) status (İcduygu and Soner 2006). As protected groups, Christian and Jewish communities had religious, educational, juridical, and fiscal autonomy. Their community lives were organized around and governed by their religious authorities, patriarchs, or rabbis, who were responsible for the discipline in their communities and answered to the Ottoman ruler (Melson 1982). In return, these communities paid extra taxes, and their members could not serve as state officers or in the military (Zürcher 2004).

The destiny of the millet system as well as that of modern Armenian-Turkish relations were shaped during the gradual collapse of the Ottoman Empire between the late eighteenth and early twentieth centuries. The main cause of the collapse was the empire's lost wars against European powers and the independence movements of its minorities. To prevent the imminent collapse, the Ottoman authorities not only took security measures, they also implemented various political reforms to emancipate their non-Muslim subjects and to integrate them more firmly into Ottoman society: the Nationality Law of 1869 promised equality before the law to all citizens. In the late nineteenth and early twentieth centuries, the inclusive process reversed and paved the way for competing nationalisms and ethnic violence in the Ottoman Empire. The most notorious outcome of the hostility was the 1915-1917 deportations organized by the Committee of Union and Progress (CUP), referred to as the Armenian genocide (Göçek 2014, also see Bloxham 2011). According to Levene $(1998,397)$, between 600,000 and over a million Armenians were killed, out of a population of two million in total, which served the CUP's ambition to create a modern ethnically Turkified nation-state in the Anatolian mainland. There is a highly charged political and scholarly debate about genocide recognition (Yavuz 2011), which is beyond the scope of this article.

The Ottoman Empire collapsed at the end of World War I along with the Central Powers. This was followed by the signing of the Treaty of Sèvres between the Ottoman Empire and the Allies in 1920, which contained heavy conditions such as the allocation of most of the imperial territory to the Allies and independent states of Kurds and Armenians. The reaction to the conditions paved the way for the resistance movement that waged and won the Turkish War of Independence (19191923). Subsequently, the signing of the Lausanne Treaty in July 1923 led to the establishment of the Republic of Turkey. The new treaty marked the end of the millet system and non-Muslim minorities' transition to modern citizenship by providing them equal rights. Nevertheless, Ekmekçioglu states that the boundaries between the Armenian minority and the Turkish majority were still maintained in the social structure:

The in -side of the community was composed of Armenian families, homes, and kinship networks. The mid -side of the community was made up of churches, schools, charitable organizations, and cemeteries in which Armenians related to other Armenians but by law and regulations, these spaces were under state surveillance. The out -side of the community was the realm of non-Armenians, the Turkish public sphere, and the state. (Ekmekçioğlu 2016, 13)

In addition, the equal rights granted to non-Muslim minorities did not match the de facto treatment. Aktürk (2009) argues that the definition of the Turkish nation only included Muslim citizens and, in so doing, reproduced the exclusionary rationale of the Ottoman millet system. 
Üngör (2011) states that the nationalist population policies aimed at ethnically homogenizing the Eastern region of Turkey between 1913 and 1950 using genocide, deportation, spatial planning, forced assimilation, and memory politics. Moreover, although the Wealth Tax of 1942 intended to tax people who made fortunes from the wartime economy, it was too heavy-handed on nonMuslims (Neyzi 2002). On September 6-7, 1955, due to the Cyprus crisis, there was a riot against the Greek minority, which got out of hand and turned into xenophobic violence against all non-Muslim minorities in Istanbul. Kuyucu (2005) views these events as a part of the Turkish state's project of transferring economic capital from non-trustable non-Muslim communities to Turks. Various international events seem to have negatively influenced the perception of Armenians in Turkey. Most importantly, the Turkish state endeavored to prevent the international recognition of the 1915-1917 Ottoman violence against the Armenians as genocide (Gürpınar 2016). It is seen as an offensive allegation in Turkey and adds to the negative perception of Armenians.

This study affords a fresh perspective by examining the political perception of Armenians in Turkey in an underexplored period, the beginning of the multiparty democracy (1946-1960). This is a very interesting context, as it coincides with the beginning of post-World War II era politics and the end of single-party domination in Turkey. The period also marked a successful passage to the classical mechanism of European parliamentarianism and the ideas of social democracy in Turkey (Karpat 2004), which helps in exploring the perception of Armenians in competing political parties' speeches, namely the Republican People's Party (Cumhuriyet Halk Partisi, CHP) and the Democrat Party (Demokrat Parti, DP). Moreover, the parliament reflected on notable events, such as the events of September 6-7, 1955. As Aytürk (2014) points out, the Islamist discourse started to have more impact on Turkish nationalism during the 1950s, paving the way for the rise of political Islam in Turkey as well as influencing the general perception of non-Muslim minorities. Further, the period comes just before the ASALA's terrorist attacks against Turkish diplomats and civilians. Thus, it provides an invaluable opportunity to explore Turkish politicians' attitudes towards the community in the absence of strong Turkish reactions to the ASALA. Below, the article first links group position theory with relevant perspectives from the academic literature on the Turkish perception of non-Muslims to provide a fresh theoretical approach. Subsequently, it explains the research context, procedures, and methodological choices. Finally, it presents the qualitative and quantitative findings and discusses their implications.

\section{Theoretical Approach}

\section{The Contribution to the Scholarship}

Academic studies on the non-Muslim minorities in modern Turkey focus on different contexts and most often demonstrate such exclusionary policies and practices as the Wealth Tax of 1942 (Aviv 2017; Bali 1998, 2001, 2004, 2006; Brink-Danan 2012; Göl 2005; Haker 2003; Toktas 2005). Indeed, subsequent to the establishment of the Republic of Turkey in 1923, non-Muslim minorities, namely Armenians, Greeks, and Jews, gradually emigrated from the country (Aktürk 2017). While the academic literature about the Armenian community generally revolves around the analysis of the Turkish opposition to the claim of international genocide recognition (Açar and Rüma 2007; Akçam 2004; Avedian 2013; Bilali 2013; Dixon 2010; Yavuz 2011), few studies present valuable insights from the experience of the Armenian minority in modern Turkey (e.g., Ekmekçioğlu 2016). Drawing on an analysis of the period between 1930 and 1950, Suciyan (2018) argues that the Armenians were a silenced and repressed community forced to echo the Turkish state's official position and, accordingly, their persecution in the Ottoman Empire continued in the Republic of Turkey. The scholarship lacks general theoretical insight about the social and political factors that contribute to negative and intolerant speeches about non-Muslim minorities in modern Turkish politics.

Group position theory as a generic perspective could explain the significant contributors to the negative perception of Armenians in Turkish politics and society in different periods. It proposes 
that intergroup prejudice emerges from dominant group members' perception of outgroups as a threat to their prerogatives. This idea rests on two basic postulates: (a) dominant group members see themselves as entitled to have privileges; (b) when they perceive threats to their privileges, they would endorse negative views about subordinate groups. In other words, group position theory underlines the social position of dominant group members as a strong indicator of their perception of others. The approach builds on Blumer's (1958) theoretical perspective, which mentions four kinds of feelings in prejudiced attitudes: (1) dominant group superiority; (2) the essential difference of subordinate groups from the dominant group; (3) the proprietary claim of the members of the dominant group to certain areas of privilege and advantage; (4) anxiety about other groups' interests and designs on the privileges of the dominant group. Blumer (1958) finds the third feeling the most prominent and conceptualizes prejudice as a defensive reaction against perceived threats. According to this perspective, through prejudice, dominant group members seek to defend their historically and collectively developed social positions.

This theory predicts that negative perceptions of outgroups would grow in parallel to an increase in their population and worsening economic conditions. The majority of the scholarship focuses on the relationship between dominant groups' attitudes and their perceived threats and the sizes of minority groups in developed countries (Biggs and Knauss 2012; Schneider 2008; Semyonov and Glikman 2009). In other words, the scholarly emphasis is on the micro-level perception of individuals and the Western world. This constitutes an important geographical and methodological limitation, as the historical, political, and contextual influences on prejudice are not sufficiently analyzed. Indeed, Quillian $(1995,1996)$ notes an important lack of studies on the historical and cultural components of dominant groups' negative attitudes towards outgroups. The academic literature can also expand its horizons through empirical studies in less developed countries, where the social dynamics of prejudice could have significant differences. Through employing group position theory to understand the perception of Armenians in Turkey, this study not only contributes to the literature on Turkish-Armenian relations from a novel sociological perspective, it also expands the group position scholarship through its macro-level focus on an underexplored context as well as by accounting for the historical background of the negative views.

\section{The Sèvres Syndrome as a Foundational Perceived Threat in Modern Turkish Politics}

Hiers, Soehl, and Wimmer (2017) suggest that past conflicts and territory losses can foster a strong form of national, religious, and ethnic identification as well as an increased level of hostility towards nonnationals. They highlight that in a comparison of 33 European countries, Turkey and Russia are the top countries with regards to perceived threats. An important source of such anxieties prevalent in Turkish politics is the Sèvres syndrome, an insecurity and alertness about the potential threats against Turkish national borders posed by the alleged collaboration of external enemies and the minorities in the country (Göçek 2011; Guida 2008; Nefes 2015; İcduygu and Kaygusuz 2004). The syndrome is inherited from the downfall of the Ottoman Empire, which was mainly due to wars with external enemies and to conflict with the independence movements of its minorities. Indeed, the name comes from the Treaty of Sèvres in 1920, which created a significant trauma in Turkish political memory, as it meant the empire's ultimate collapse. Although named after the treaty, the Sèvres syndrome dates back to long before in the early nineteenth century, when the Ottoman loss of land became the most important problem. In other words, the Treaty of Sèvres does not represent the beginning of these anxieties but their realization. A clear example of the syndrome predating the treaty is manifest in a letter sent by the Sultan Abdulhamid II to Sir Philip Currie, the British ambassador of the period. The sultan attempted to justify the violent measures taken against the Armenians at Sassoun in August 1894. He claimed that the Armenians created exaggerated accounts about their suffering under Ottoman rule to gain the support of the European powers in establishing an independent state just as the Bulgarians had in their independence from the Ottoman Empire: 
His Majesty says that your Excellency will remember that the Bulgarians, [sic] concocted the same stories against the Government, and proceeded just as the Armenians do, and that the British Government extended a certain protection to the Bulgarians, who have now been formed into separate provinces. This cannot possibly, however, happen in the case of the Armenians. The Armenian population is spread over a large extent of the country, and in no place are they a majority. Their expectations, therefore, can never be realized, and all the exaggerated stories of oppression and persecution, got up with the object of exciting European sympathy to enable them to obtain an impossible end, should not be relied upon.... Naturally the Ottoman government was bound to take strong measures to put down sedition, and when people were found with arms in their hands resisting the authorities, it was only natural that the Government should mete out to them summary punishment. (Melson 1982, 501-502)

As Zürcher $(2011,308)$ remarks, the founding elite of the Republic of Turkey also dealt with the "trauma of territorial loss and military defeat." One could read how they came to terms with the Sèvres syndrome in the first line of the Turkish National Anthem: "Fear not! For the crimson flag that proudly ripples in this glorious twilight, shall not fade." This line seems to unveil the centrality of the Turks' persistent anxiety about territorial loss, as it starts with an assurance against it. Mustafa Kemal Atatürk, the founding father of the republic, informed the public about the potential danger posed by any cooperation between foreign powers and non-Muslim minorities (Zürcher 2011). Although Abdulhamid II and pan-Islamism were his political and ideological enemies, Atatürk explained the violence against Armenians in the Ottoman Empire during World War I in a way reminiscent of the sultan: "Whatever has befallen the non-Muslim elements living in our country, is the result of the policies of separatism they pursued in a savage manner, when they allowed themselves to be made tools of foreign intrigues and abused their privileges" (Zürcher 2011, 313). Another more recent example of the use of the Sèvres syndrome was given by Mehmet Ağar, a former Turkish nationalist politician. When asked about the function of the deep state in Turkey with which he was associated, Ağar argued that the deep state means the determinacy to avoid giving any more ground after losing Kirkuk, the last province lost by the Ottoman Empire (Şimşek and Selamoğlu 2002).

The significance of the syndrome could be explained by its embeddedness in Turkish nationalism. Ziya Gökalp, "known as the originator of a systemic theory of Turkish nationalism" (Mardin 2007, 1999), explains the fall of the Ottoman Empire due to minority movements and the main tenets of Turkish nationalism in an interrelated manner by relying on Durkheimian sociology. In The Principles of Turkism, Gökalp $(1968,54)$ states that the dismemberment of the empire was a result of a lack of unity of culture by which he meant that the millet system helped the development of incompatible cultures and moralities within the empire that subsequently formed competing nationalisms. Thus, he advances a program of Turkism with the aim of creating a new nation based on the culture of the Hanafi Muslim population. Gökalp's (1968) program underlines how this foundational culture should be supported by the state in various areas as linguistic, aesthetic, ethical, legal, religious, economic, and political Turkism. Overall, his nationalism was a sociological attempt to avoid dismemberment like the empire by excluding all different cultural and religious groups for being incompatible with the Turkish national morality (Nefes 2013, 2018). Ünlü (2014) conceptualizes this overall change as the Turkishness Contract, which means certain ways of understanding the world from a privileged standpoint in Turkey. He claims that Turkishness is maintained with self-righteousness, selective knowledge, and apathy about minority cultures and religions. With regards to the Armenians in Turkey, this contract includes an avoidance of subjects related to the Turkish maltreatment and violence against the Armenians. By keeping this contract, Turks continue to be dominant group members in Turkey and are entitled to enjoy privileges, and if they breach this contract, they would be punished severely (Ünlü 2014).

The anxieties inherited from the Ottoman dissolution seem to have shaped Turkish nationalism, which trusts Muslim Turks as the dominant group whose privileges could be threatened by 
minorities' desire to become independent under the sponsorship of foreign powers. That is to say, using group position theory in Turkish politics must provide insight into the historical background of the perceived threats, particularly the Sèvres syndrome. This study proposes that security threat perception is an important contributing factor to the negative views about Armenians in Turkish politics. This premise is in line with various studies in the academic literature about the Armenian community in modern Turkey. Göl (2005) argues that the Turkish state's perceived threats about Armenian claims on its territory ignite the exclusionary state policies about the community. Besides, this theoretical perspective could contribute to the discussion about the violence during the Ottoman period. For example, with regards to the massacres between 1894-96, Melson (1982) criticizes what he calls the provocation thesis: the Armenian revolutionary groups were responsible for triggering the massacres by provoking the Ottoman authorities with their armed struggle for self-administration in a period when the empire was overwhelmed by the Great Powers' interventions (Shaw and Shaw 1977). Melson (1982,493-4) notes that this theory does not provide sufficient evidence on whether the Armenian revolutionaries posed a genuinely serious threat and the reasons for the Ottoman government to perceive them as a threat. Group position theory affords a more comprehensive theory than provocation theory's action-reaction model by delineating how traumatic experience emanating from real security threats, such as past territorial loss, could lead to the parallel processes of the fortification of the dominant group's identity and an enduring exclusion of minorities even in the absence of any serious threat, along with denying, ignoring, justifying, or belittling the violence they suffered.

\section{Data and Method}

This article scrutinizes the Turkish parliamentary records with a particular focus on the kinds of debates in which politicians were more likely to express negative views about Armenians and the extent to which these discussions were provoked by perceived threats. It examines the parliamentary proceedings between 1946 and 1960, the beginning of the multiparty period. During this era, the parliament mainly witnessed debates between two major political parties: the CHP and DP. The CHP was in government between 1946 and 1950, and the DP formed the government in the following three terms until being interrupted by a military coup in 1960 .

Parliamentary records are an excellent source to analyze political debates (Draege 2019). First, they include all-encompassing data about political debates. For example, this article explores all parliamentary discussions that included mentions of Armenians. Second, the digitalized archives can be easily obtained and rapidly searched for keywords on any topic of interest. Third, they contain firsthand data of entire speeches, at times including reactions from the benches. In that regard, studies can draw on natural observations of political debates, and politicians' arguments do not go through any editorial filter as could happen in newspapers or journals. Fourth, parliamentary records afford evidence from mainstream politics with policy implications. In the case of this article, the speeches that could have direct real-life impact on the Armenian minority in Turkey between 1946 and 1960 are all included. Fifth, parliamentary proceedings comprise comprehensive information about how different political parties' approaches on any topic may vary. Last, in many research areas, such as the perception of minorities, parliamentary debates constitute an underexplored source.

To investigate this invaluable source thoroughly, this study uses both quantitative and qualitative content analysis in a complementary manner. The quantitative inquiry presents an overall picture of the relationship between the discussions about perceived security threats and the descriptions of Armenians in political speeches using statistical evidence. Triangulating the quantitative results, a qualitative analysis shows the ways in which MPs describe Armenians and justify their accounts. In other words, while the statistical evidence points to the MPs' inclination towards negative descriptions of Armenians, the qualitative part reveals their reasons. This helps in exploring both the manifest and latent aspects of political communication and in ensuring the validity and reliability of 
Table 1. Codebook

\begin{tabular}{ll}
\hline Perception & $\begin{array}{l}\text { NEGATIVE: Description of Armenians' identity, existence, or actions in unfavorable terms, which includes } \\
\text { defending an unfavorable treatment or perception of Armenians. }\end{array}$ \\
& NEUTRAL: Description of Armenians' identity, existence, or actions in value-free terms. \\
& $\begin{array}{l}\text { POSITIVE: Description of Armenians' identity, existence, or actions in favorable terms, which includes } \\
\text { criticizing an unfavorable treatment or perception of Armenians. }\end{array}$ \\
\hline $\begin{array}{c}\text { Debate } \\
\text { Topic }\end{array}$ & $\begin{array}{l}\text { SECURITY THREATS: Debates on past and present security threats to Turkey: the perceived threats by the } \\
\text { Soviet Union, the Ottoman-Armenian conflict between the late eighteenth and early twentieth } \\
\text { Centuries, and the National Salvation struggle. }\end{array}$ \\
& $\begin{array}{l}\text { EDUCATION: Debates on the Turkish schooling system. } \\
\text { CULTURE: Discussions on culture and cultural products, such as music, language, and religious artifacts. }\end{array}$ \\
& $\begin{array}{l}\text { POLITICS: Discussions about contemporary political developments and politicians: the September 6-7 } \\
\text { pogrom, secularism, media, women's rights, and criticism of a DP member. }\end{array}$ \\
& $\begin{array}{l}\text { HEALTH: Talks on the Turkish medical system. } \\
\text { CRIME: Debates about criminal activities. }\end{array}$ \\
\hline JUSTICE: Discussions on the Turkish justice system. \\
\hline
\end{tabular}

the findings. Moreover, mixed-method content analysis has various advantages in answering complex research questions, such as enabling a numerical interpretation of effect sizes of qualitative findings (Onwuegbuzie 2003; for other benefits, see Cabrera and Reiner 2018; Chi 1997; Woodrum 1984). Of particular relevance is the process of quantifying, assigning numerical values to nonnumerical data (Tashakkori and Teddlie 1998).

The author of this article and the research assistant (RA) analyzed the parliamentary proceedings and coded the content into quantitative categories to create a dataset. The unit of analysis was an individual speech. First, the author collected all the speeches $(\mathrm{N}=55)$ in the Turkish parliamentary proceedings between 1946 and 1960 that contain the word Armenian, Ermeni in Turkish. Second, we read the content of the speeches and created a coding book for the analysis, as shown in Table 1 below. We coded texts separately into two main categories: (a) perception of Armenians; and (b) the debate topic in which Armenians are mentioned, and then compared our codes. We calculated the coding agreements percentages as well as Scott's pi, which accounts for the probability of agreeing by chance (Potter and Levine-Donnerstein 1999). The results show that with regards to the perception of Armenians, we have a 92.7\% (51 agreement out of 55 entries) simple intercoder agreement (Scott's pi=.85). Neuendorf (2002) finds simple agreement levels of $80 \%$ and higher as acceptable for most variables. In our study, achieving high agreement rates could be related to having simple binary categories as underlined by Carley (1993) as well as the simplicity of the coding instructions, coder training, and diligence as highlighted by Sanders and Cuneo (2010). Last, as the electronic files of the parliamentary records were prepared by scanning the existing documents, there might have been problems with the search function. We could have been missing certain instances of mentions of Armenians. We addressed this issue by conducting reliability checks in all documents by randomly choosing a sentence from each and using the search function for each word. This gave an estimation of whether the search would miss any words. We did not encounter any problems in these reliability checks.

To differentiate what is coded as a negative perception, an example could be given from Sinan Tekelioğlu's (DP) speech: “The French military forced the Turkish inhabitants of Adana out of the city. A convoy of these people, around a hundred people including women and children, were attacked by the Armenian forces, who indiscriminately raped and killed the children and adults." ${ }^{1}$ Here, the MP negatively describes Armenians as a ruthless enemy in his account about the National 
Salvation period. The neutral descriptions are mentions of Armenians without any negative or positive associations. Emin Soysal's speech is an apt example: "An Armenian citizen buys the farm and then, sells it to another citizen from Istanbul." 2 This sentence does not attach any values to Armenians and, therefore, is coded as neutral. A positive comment is manifest in Hamdullah Suphi Tanriover's (CHP) speech: "Two ladies, members of the Ottoman royalty, were experiencing extreme poverty in Paris. They were searching for food in rubbish bins. Local Armenians, who were our former citizens, noticed the situation and helped these ladies in any way imaginable, even by renting accommodation for them."' ${ }^{3}$ Tanriover praises the Armenians' charitable behavior, and for that reason, his speech is coded as a positive description. Coding debate topics was more straightforward, as there is an index in each session that describes the debate topic in one sentence. Combined with the content of the politicians' speeches, this made understanding in what kind of debate Armenians are mentioned less subjective than recognizing whether they are portrayed in a negative, neutral, or positive manner.

\section{Perceived Security Threats and Descriptions of Armenians}

In line with group position theory, this article explores the relationship between debating about the security threats to Turkey and describing Armenians negatively. It expects that politicians would be more likely to portray Armenians negatively during those debates related to security threats because of their anxiety about their prerogatives, likely the continuity of the republican regime and its territorial integrity, as any changes to them would threaten the established social, political, and economic order. Thus, the study focuses on negative comments and discussions about perceived security threats. It separated the negative comments from the others and generated another binary variable that divided the debates between security threats and other topics. The former includes three discussions on the threat of Soviet communism to the regime, eight discussions about the Turkish War of Independence, and two debates about the Ottoman- Armenian conflict between the late eighteenth and early twentieth centuries. The other debates were on politics, culture, crime, economy, education, and the justice and health systems, as summarized in Table 1 above.

The frequencies of the mentions of Armenians in Table 2 below demonstrate that when the discussion topic reflects security threats, the description of Armenians is most likely to be negative. Indeed, in 12 of the 13 speeches about security threats, MPs portrayed Armenians negatively. With regards to the other debates, such as education and culture, the likelihood of the negative perception of Armenians decreases significantly, as only ten of the 42 speeches delineated Armenians in unfavorable terms.

Binary logistic regression analysis not only helps confirm whether there is a statistically significant relationship between the negative perception of Armenians and the debate subjects, it also provides further information about the effect sizes of discussing certain topics on politicians' descriptions of Armenians through odds ratios and Nagelkerke's R Square. As seen in Table 3 below, despite having a relatively small sample size $(\mathrm{N}=55)$, the model demonstrates that the topic of security threats is a very significant predictor of the negative perception of Armenians $(\mathrm{p}<.01)$.

Table 2. Armenian perception and debate topic

\begin{tabular}{llccr} 
& \multicolumn{2}{c}{ Topic } & \\
\cline { 3 - 4 } & & Security threats & Others & Total \\
\hline \multirow{2}{*}{ Perception } & Non-negative & 1 & 32 & 33 \\
\cline { 2 - 5 } & Negative & 12 & 10 & 22 \\
\hline \multirow{2}{*}{ Total } & 13 & 42 & 55 \\
\hline
\end{tabular}


Table 3. Binary logistic regression of the negative perception of Armenians

\begin{tabular}{lcccc}
\hline & & & \multicolumn{2}{c}{$95 \%$ confidence interval } \\
\cline { 4 - 5 } & B (SE) & Odds & Lower & Upper \\
\hline Discussing security threats & $3.648^{\star *}(1.102)$ & 38.4 & 4.428 & 332.985 \\
\hline Constant & $-1.163^{\star *}(.362)$ & .313 & \\
\hline
\end{tabular}

Note: $R^{2}=.39$ (Hosmer \& Lemeshow), .316 (Cox \& Snell), .427 (Nagelkerke).

Model $\chi 2(1)=20.875,{ }^{\star} \mathrm{p}<.05,{ }^{\star *} \mathrm{p}<.01,{ }^{\star \star \star} \mathrm{p}<.001$

The table also shows that the odds of Armenians being described negatively is 38.4 times higher when Armenians are mentioned in a discussion on threat-related topics than in other debates. Moreover, Nagelkerke's R Square is 0.427 , indicating a relationship between prediction and grouping. In sum, the regression analysis confirms that discussing threat-related topics is a reliable indicator for predicting negative remarks about Armenians.

\section{How Did MPs Relate Security Threats to Their Comments on Armenians?}

This section is centered on a qualitative analysis of the relationship between MPs' negative comments and the debate topics. It also scrutinizes the contrasting cases, politicians' positive descriptions of Armenians, to provide a more comprehensive and balanced account. To start with the negative descriptions, Table 4 below summarizes the debates in which Armenians were negatively portrayed. Most of these comments occurred in discussions about security threats, and MPs portrayed the Armenian community as an enemy. The other debate topics that contained negative expressions about Armenians were on culture, crime, politics, and the health system. In these debates, MPs focused on the negative behaviors of individual Armenians not the entire community. In short, discussing national security matters seems to be a unique factor associated with the negative perception of Armenians.

The majority of negative mentions were during the discussions on security threats. MPs were talking about the Turkish War of Independence (1919-1923), foreign threats of Soviet communism, and internal security problems during the Ottoman-Armenian conflict between the late eighteenth and early

Table 4. Negative mentions of Armenians and debate topics

\begin{tabular}{llr}
\hline General Topic & Particular Mention & Frequency \\
\hline \multirow{2}{*}{ Security } & The Turkish War of Independence & 8 \\
\cline { 2 - 3 } & Foreign threats of communism & 3 \\
\cline { 2 - 3 } & Ottoman-Armenian conflict & 1 \\
\hline Culture & Islam & 2 \\
\cline { 2 - 3 } & Turkish language & 1 \\
\cline { 2 - 3 } & Turkish theater & 1 \\
\hline Crime & Criminal activities & 3 \\
\hline Health & The local problems of Seyhan & 1 \\
\hline Politics & Name change of a city to Artvin & 1 \\
\hline Total & & 21 \\
\hline
\end{tabular}


twentieth centuries. First, MPs described Armenians as an enemy while referring to the Turkish War of Independence. Latif Aküzüm from the CHP reminisced about the heroism of the local population of a city called Kars: "This government owes the success of the national defence against the invasion attempts of the Dashnak Armenians [an Armenian nationalist and socialist political party (Gunter 2007)] and Georgians to the valour of the people of Kars." ${ }^{\prime 4}$ One interesting aspect of these comments is that most came from MPs from the Seyhan region (currently known as Adana), which witnessed a prolonged struggle against Armenians (Moumdjian 2008). Sinan Tekelioğlu (CHP) mentioned that "with a very small group of soldiers, I was fighting against the French army and 28 regiments of Armenian volunteers. Who would have guessed that we would dare to fight against such a powerful enemy?" Second, MPs argued that the Armenian community is very susceptible to manipulation by foreign powers. Fahrettin Ecevit (CHP) stated that "duped by Russians, Armenians began to propagate against Turkey in the United States, falsely claiming that we are not a suitable country for democracy." 5 Third, MPs approached Armenians as an enemy when it came to internal threats. Referring to the Armenians massacres in the Ottoman Empire in 1895 (Deringil 2009), Faik Erbaş (DP) used pejorative words against Armenians, which received protests from other MPs in the audience: "Thank God that I have no stain in my family tree. My father did not cry during the 1313 Armenian incident; I am a pure-blooded Turkish person [Grumble from the benches: "shame, shame"]." 6

MPs' negative descriptions predominantly targeted individual members of the community when debating about topics related to culture and crime. With regards to the former, they were critical of some of the Armenians' cultural insensitivities. For example, Izzet Akçal (DP) recounted the case of an Armenian citizen who converted an unused mosque into a stable: "In 1950, Muslim residents of Samanpazarı, Ankara, were furious with an Armenian citizen for populating a mosque with animals." 7 During the parliamentary discussions about crimes, Armenians were often described as criminals. Ali Fahri Işeri (DP) mentioned the case of an Armenian smuggler while talking about a corruption case in the police force. In the debates about local matters, such as changing the name of a city, Çoruh, to Artvin, MPs spoke unfavorably about the general Armenian identity. Omer Lutfi Erzurumluoğlu (DP) assured his colleagues that Artvin is not an Armenian word: "Indeed, the word Artvin means belly or back in ancient Turkish."

When we look at the positive comments about Armenians, it seems that some MPs appreciated the contributions of individual members of the community. Table 5 below outlines the discussions in which MPs portrayed Armenians in a favorable light. While debating about the September 6-7 attacks, Zakar Terver (DP) reminded listeners that the Armenians and Greeks who had been targeted were exemplary citizens: "We all know about the invaluable service of Armenians for centuries. Well-known medical doctors such as Antanik Pasha, great architects such as the Balyans, who designed the Selimiye Military Barracks, Beylerbeyi Palace and Dolmabahce Palace."9 MPs also

Table 5. Positive mentions of Armenians and debate topics

\begin{tabular}{llr}
\hline General Topic & Particular Mention & Frequency \\
\hline \multirow{2}{*}{ Politics } & The September 6-7 pogrom & 1 \\
\cline { 2 - 3 } & Ottoman Imperial family return & 1 \\
\cline { 2 - 3 } & The land ownership law & 1 \\
\hline Culture & Music & 1 \\
\cline { 2 - 3 } & Turkish language & 1 \\
\hline Economy & Street beggars & 1 \\
\hline Education & Faculty of Medicine & 1 \\
\hline Total & & 7 \\
\hline
\end{tabular}


highlighted the other contributions of Armenians. Cezmi Türk (DP) noted that "the first teachers of the Medical School of Haydarpasa, established during the rule of the Ottoman Sultan Abdul Mecid, were our Armenian and Greek citizens." ${ }^{10}$ Further, Vasfi Mahir Kocatürk (DP) praised an Armenian for his contribution to the Turkish literature: "Semseddin Sami's great encyclopaedia was published 40 years ago by an Armenian citizen, called Mihran."11

Parallel to the quantitative analysis, the qualitative inquiry points to the significance of perceived security threats on the negative perception of Armenians in the Turkish parliamentary speeches. First, MPs described the entire Armenian community as an enemy only in the security-related debates. In the others, politicians either praised or condemned individual members of the community. While the unfavorable descriptions of individual Armenians still contributed to the negative perception of the community, this constitutes a laxer attitude compared to seeing the group as an enemy. Second, MPs from the Seyhan region, which experienced a prolonged struggle with Armenians during the Turkish War of Independence, referred back to this period and reminded listeners that Armenians were the enemy. Third, in the only case of a clearly racist comment by Faik Erbaş (DP), which was cited above and glorified having pure Turkish blood, the other MPs immediately censured Mr. Erbaş. If the racist sentiment resonated with the audience, they would not have scorned the speaker. Indeed, in no other debates in this dataset did we see any audience grumble to the speakers. Last, both the CHP and DP members talked negatively about Armenians in an undifferentiable manner. That is to say, political party membership did not make any difference in the perception of Armenians, which further underscores the significance of perceived security threats as an important factor.

\section{Conclusion}

To date, the scholarship has not sufficiently analyzed mainstream Turkish politics between 1946 and 1960 to understand the significant factors that feed the negative perception of Armenians in modern Turkey. This study contributes to fill this gap by exploring the entire spectrum of Turkish parliamentary speeches in that period. The findings support the main premise built on group position theory and suggest that perceived security threats significantly contribute to Turkish political parties' negative descriptions of Armenians. The quantitative content analysis demonstrates that debating about security threats is a reliable predictor of negative descriptions. Indeed, a substantial proportion of the speeches that referred to security threats contained negative statements about Armenians. Triangulating the validity of these findings, the qualitative content analysis provides further evidence via a detailed view of the political rationale behind the negative descriptions of Armenians. In particular, it highlights that the Turkish political parties labeled the Armenian minority as an enemy in nearly all security-related discussions, whereas they criticized individual Armenians in others. In addition, being a member of the CHP or DP did not make any difference in the politicians' tones, which underscores that the debate topics were more important indicators of negative perception than political party membership.

All in all, group position theory seems to explain a substantial amount of the negative descriptions of Armenians between 1946 and 1960. The study concludes that perceived security threats are important factors that trigger hostility towards Armenians in modern Turkish politics. This could mean that Turkish politics contains a historically conditioned hostility towards the community rather than a primordial hatred against all Armenians in all contexts. Indeed, from its establishment, Turkish politics inherited the perception of an existential threat, the Sèvres syndrome (Göçek 2011; Guida 2008), that distrusts the intentions of foreign powers and local minorities, which seems to constitute a significant component of the intolerant speeches in Turkish politics. According to a recent report on the use of hate speech in Turkish media (Dink Foundation 2019), Armenians were the group most frequently targeted by hate speech in 2019 and labeled as an enemy community posing a threat to Turkey, both currently as well as during the period of the 
Turkish Independence War, and also to Azerbaijan in the Nagorno-Karabakh conflict. This implies that perceived threats to national security present a challenge to democracy and human rights by viewing religious, ethnic, and political minorities as a potential fifth column and triggering intolerance. Hence, Turkish society and politics could benefit from a more effective management of perceived security threats to become more inclusive.

However, this would not end the hostility towards the Armenian minority but probably only silence it temporarily, because the findings also support the argument that as non-Muslims in Turkey, Armenians constitute an excluded minority. The applicability of group position theory by itself implies that Armenians are not seen as part of the dominant group or nation in Turkey. Unless their members made great achievements, or were hate crime victims in the September 6-7 events, Armenians were described as outsiders in Turkish parliamentary proceedings between 1946 and 1960. Even in the case of great contributions to Turkey, they were labeled as "our Armenian citizens" not as "our citizens," as would happen in the case of a Muslim. This finding resonates with various studies (e.g., Aktürk 2009; Ekmekçioğlu 2016; Suciyan 2018; Üngör 2011), such as Ünlü's (2014) Turkishness contract, which proposes that non-Muslim minorities are seen as subordinate groups in modern Turkey. In parallel, Gökalp's $(1968,119)$ religious Turkism of the 1920s, which had an important influence on modern Turkish nationalism, recommends that Islamic sermons and prayers be delivered in Turkish to enable people to understand their religion better, implying that the modern Turkish nation will be Muslim. A joke about the Turkish-Armenian popstar Rober Hatemo in the popular comedy series Kardeş Payt in 2015 and his reaction is exemplary to this perception. In the series, while trying impress girls, one character boasts about listening to foreign music all the time and names Rober Hatemo as his favorite foreign singer. Hatemo reacted on social media by sharing his and his grandfather's Turkish national identity cards and stating that he is not a foreigner (Karar 2015).

It should not go without saying that parliamentary proceedings afford a very rich and underexplored data source on the perception of minorities. Future research could benefit from the easy online access to these official records in various countries. This would also render it possible to make international comparisons of ethnoreligious hostility. In parallel, future studies could test the validity of findings by examining the significance of threat perception on political decisions about other minorities and refugees in Turkey, such as the Syrians. This would not only provide a fresh approach to understanding the roots of ethnic and religious hostility in the country but could also inform important policy decisions.

Acknowledgments. This research was made possible by a Gulbenkian Foundation research grant (no: 211728). I would also like to acknowledge my gratitude to the research funding from the Brasenose College at the University of Oxford, which provided the opportunity to develop this study for publication. I would also like to thank Mr. Ari Sekeryan, my research assistant in this project, for his help. I have no conflict of interest to declare.

Disclosure. Author has nothing to disclose.

Funding Statement. Fundação Calouste Gulbenkian 211728.

\section{Notes}

1 Türkiye Büyük Millet Meclisi (TBMM), Tutanak Dergisi, Term 10, Legislative Year 2, Sitting 47 (02.23.1955), p. 579.

2 TBMM, Tutanak Dergisi, Term 8, Legislative Year 5, Sitting 62 (03.10.1950), p. 296.

3 TBMM, Tutanak Dergisi, Term 9, Legislative Year 3, Sitting 85 (06.16.1952), p. 284.

4 TBMM, Tutanak Dergisi, Term 9, Legislative Year 5, Sitting 49 (02.24.1954), p. 825.

5 TBMM, Tutanak Dergisi, Term 8, Legislative Year 1, Sitting 8 (08.26.1946), p. 136.

6 TBMM, Tutanak Dergisi, Term 9, Legislative Year 3, Sitting 52 (03.24.1952), p. 13.

7 TBMM, Tutanak Dergisi, Term 11, Legislative Year 3, Sitting 36 (02.12.1960), p. 690. 
8 TBMM, Tutanak Dergisi, Term 10, Legislative Year 3, Sitting 38 (02.17.1956), p. 269.

9 TBMM, Tutanak Dergisi, Term 10, Legislative Year 2, Sitting 80 (09.12.1955), p. 674.

10 TBMM, Tutanak Dergisi, Term 9, Legislative Year 3, Sitting 88 (06.20.1952), p. 422.

11 TBMM, Tutanak Dergisi, Term 9, Legislative Year 4, Sitting 53 (02.25.1953), p. 993.

\section{References}

Açar Arikan, Dilaver, and İnan Rüma. 2007. "External Pressure and Turkish Discourse on 'Recognition of the Armenian Genocide.”' Southeast European and Black Sea Studies 7 (3): 449-465.

Akçam, Tamer. 2004. From Empire to Republic: Turkish Nationalism and the Armenian Genocide. London and New York: Zed Books.

Aktürk, Şener. 2017. "Post-imperial Democracies and New Projects of Nationhood in Eurasia: Transforming the Nation through Migration in Russia and Turkey." Journal of Ethnic and Migration Studies 43 (7): 1101-20.

Aktürk, Şener. 2009. "Persistence of the Islamic Millet as an Ottoman Legacy: Mono-religious and Anti-ethnic definition of Turkish Nationhood.” Middle Eastern Studies 45 (6): 893-909.

Avedian, Vahagn. 2013. "State Identity, Continuity, and Responsibility: The Ottoman Empire, the Republic of Turkey and the Armenian Genocide.” The European Journal of International Law 23 (3): 797-820.

Aviv, Efrat. 2017. Antisemitism and Anti-Zionism in Turkey: from Ottoman Rule to AKP. London, UK: Routledge.

Aytürk, Ilker. 2014. "Nationalism and Islam in Cold War Turkey, 1944-69." Middle Eastern Studies 50 (5): 693-719.

Bali, R. 2006. "The politics of Turkification during the single party period.” In Turkey Beyond Nationalism: Towards Postnationalist Identities, edited by H. K. Keiser, 43-50. London, UK: Health Press.

Bali, Rifat. 2004. Devlet'in Yahudileri ve 'Oteki' Yahudi. Istanbul, Turkey: Iletisim Yayinlari.

Bali, Rifat. 2001. Musa'nin Evlatlari Cumhuriyet'in Vatandaslari. Istanbul, Turkey: Iletisim Yayinlari.

Bali, Rifat. 1998. “Cumhuriyet Döneminde Azınlıklar Politikası.” Birikim 9 (7): 80-90.

Barkey, Karen. 2008. Empire of Difference: The Ottomans in Comparative Perspective. New York: Cambridge University Press.

Biggs, Michael, and Steven Knauss. 2012. "Explaining Membership in the British National Party: A Multilevel Analysis of Contact and Threat." European Sociological Review 28 (5): 633-646.

Bilali, Rezarta. 2013. "National Narrative and Social Psychological Influences in Turks' Denial of the Mass Killings of Armenians as Genocide." Journal of Social Issues 69 (1): 16-33.

Bloxham, Donald. 2011. "The First World War and the Development of the Armenian Genocide." In A Question of Genocide, edited by R. Suny, F. Göçek, and N. Naimark, 260-275. Oxford, UK: Oxford University Press. doi: 10.1093/acprof: osobl/9780195393743.003.0013

Blumer, Herbert. 1958. "Race Prejudice as a Sense of Group Position." The Pacific Sociological Review 1 (1): 3-7.

Bobo, Lawrence. 1999. "Prejudice as Group Position.” Journal of Social Issues 55 (3): 445-472.

Brink-Danan, Marcy. 2012. Jewish Life in 21st-Century Turkey: The Other Side of Tolerance. Bloomington, Indianapolis: Indiana University Press.

Cabrera, Laura, and Peter Reiner. 2018. "A Novel Sequential Mixed-method Technique for Contrastive Analysis of Unscripted Qualitative Data: Contrastive Quantitized Content Analysis.” Sociological Methods \& Research 47 (3): 532-548.

Carley, Kathleen. 1993. "Coding Choices for Textual Analysis: A Comparison of Content Analysis and Map Analysis." Sociological Methodology 23 (1): 75-126.

Chi, Michelene. 1997. “Quantifying Qualitative Analyses of Verbal Data: A Practical Guide.” Journal of the Learning Sciences 6 (3): 271-315.

Deringil, Selim. 2009. “The Armenian Question is Finally Closed’: Mass Conversions of Armenians in Anatolia during the Hamidian massacres of 1895-1897." Comparative Studies in Society and History 51 (2): 344-371.

Dink Foundation. 2019. “Medyada Nefret Söylemi ve Ayrımcı Söylem 2019 Raporu.” August 1. https://hrantdink.org/tr/asulis/ yayinlar/72-medyada-nefret-soylemi-raporlari/2665-medyada-nefret-soylemi-ve-ayrimci-soylem-2019-raporu (Accessed October 21, 2020.)

Dixon, Jennifer. 2010. "Defending the Nation? Maintaining Turkey's Narrative of the Armenian Genocide." South European Society and Politics 15 (3): 467-485.

Draege, Jonas. 2019. "Parliamentary Discussions in Authoritarian Contexts: Introducing a Dataset on Party Responses to Turkey’s Gezi Protests.” Mediterranean Politics. doi: 10.1080/13629395.2019.1681714

Ekmekçioğlu, Lerna. 2016. Recovering Armenia: The Limits of Belonging in Post-Genocide Turkey. Stanford: Stanford University Press.

Göçek, Muge. 2011. The Transformation of Turkey: Redefining State and Society from the Ottoman Empire to the Modern Era. London, UK: I. B. Tauris.

Göçek, Muge. 2014. Denial of Violence: Ottoman Past, Turkish Present, and Collective Violence against the Armenians, 1789-2009. New York: Oxford University Press.

Gökalp, Ziya. 1968. The Principles of Turkism. Leiden: Brill.

Göl, Ayla. 2005. "Imagining the Turkish Nation through 'Othering' Armenians.” Nations and Nationalism 11 (1): 121-139. 
Guida, Michelangelo. 2008. “The Sèvres Syndrome’ and 'Komplo' Theories in the Islamist and Secular Press.” Turkish Studies 9 (1): 37-52.

Gunter, Michael. 2007. “Armenian Terrorism: A Reappraisal.” Journal of Conflict Studies 27 (2): 109-128.

Gürpınar, Dogan. 2016. "The Manufacturing of Denial: the Making of the Turkish 'Official Thesis' on the Armenian Genocide between 1974 and 1990." Journal of Balkan and Near Eastern Studies 18 (3): 217-240.

Haker, Erol. 2003. Once upon a Time Jews Lived in Kirklareli: The Story of the Adato Family, 1800-1934. Istanbul, Turkey: The Isis Press.

Hiers, Wesley, Thomas, Soehl, and Andreas Wimmer. 2017. "National Trauma and the Fear of Foreigners: How Past Geopolitical Threat Heightens Anti-immigration Sentiment Today." Social Forces 96 (1): 361-388.

İcduygu, Ahmet, and Özlem Kaygusuz. 2004. "The Politics of Citizenship by Drawing Borders: Foreign Policy and the Construction of National Citizenship Identity in Turkey.” Middle Eastern Studies 40 (6): 26-50.

İcduygu, Ahmet, and Ali Soner. 2006. “Turkish Minority Rights Regime: Between Difference and Equality.” Middle Eastern Studies 42 (3): 447-468.

Karar. 2015. “Rober Hatemo'dan 'Uyruk' Yanıtı.” April 01. https://www.karar.com/rober-hatemodan-uyruk-yaniti-1348 (Accessed October 21, 2020.)

Karpat, Kemal. 2004. Studies on Turkish Politics and Society: Selected Articles and Essays. Boston: Brill.

Kuyucu, Tuna. 2005. "Ethno-religious 'Unmixing of Turkey’: 6-7 September Riots as a Case in Turkish Nationalism.” Nations and Nationalism 11 (3): 361-380.

Levene, Mark. 1998. "Creating a Modern 'Zone of Genocide': The Impact of Nation- and State-Formation on Eastern Anatolia, 1878-1923.” Holocaust and Genocide Studies 12 (3): 393-433.

Mardin, Şerif. 2007. “Ziya Gökalp.” In Blackwell Encyclopaedia of Sociology, edited by George Ritzer, 1999-2004. Malden MA: Blackwell Publishing.

Melson, Robert. 1982. “A Theoretical Inquiry into the Armenian Massacres of 1894-1896." Comparative Studies in Society and History 24 (3): 481-509.

Moumdjian, Garabet. 2008. "Cilicia under French Administration: Armenian Aspirations, Turkish Resistance, and French Strategems." In Armenian Cilicia, edited by Richard Hovannisian and Simon Payaslian, 457-489. United States: Mazda Publishers.

Mylonas, Harris. 2019. "Nation-building Policies in the Balkans: An Ottoman or a Manufactured Legacy?” Nations and Nationalism 25 (3): 866-877.

Nefes, Türkay Salim. 2018. “The Sociological Foundations of Turkish Nationalism.” Journal of Balkan and Near Eastern Studies 20 (1): 15-30.

Nefes, Türkay Salim. 2015. "Scrutinizing Impacts of Conspiracy Theories on Readers' Political Views: A Rational Choice Perspective on Anti-Semitic Rhetoric in Turkey.” British Journal of Sociology 66 (3): 557-575.

Nefes, Türkay Salim. 2013. "Ziya Gökalp's Adaptation of Emile Durkheim’s Sociology in his Formulation of the Modern Turkish Nation.” International Sociology 28 (3): 335-350.

Neyzi, Leyla. 2002. "Remembering to Forget: Sabbateanism, National Identity and Subjectivity in Turkey." Comparative Studies in Society and History 44 (1): 137-158.

Neuendorf, Kimberley. 2002. The Content Analysis Guidebook. Thousand Oaks: SAGE.

Olzak, Susan. 1992. The Dynamics of Competition and Conflict. Stanford: Stanford University Press.

Onwuegbuzie, Anthony. 2003. "Effect Sizes in Qualitative Research: A Prolegomenon.” Quality \& Quantity 37 (4): $393-409$.

Potter, James, and Deborah Levine-Donnerstein. 1999. "Rethinking Validity and Reliability in Content Analysis." Journal of Applied Communication Research 27 (3): 258-284.

Quillian, Lincoln. 1996. "Group Threat and Regional Change in Attitudes toward African-Americans." American Journal of Sociology 102 (3): 816-860.

Quillian, Lincoln. 1995. "Prejudice as a Response to Perceived Group Threat: Population Composition and Anti-immigrant and Racial Prejudice in Europe.” American Sociological Review 60 (4): 586-611.

Sanders, Carrie, and Carl Cuneo. 2010. "Social Reliability in Qualitative Team Research." Sociology 44 (2): 325-343.

Schneider, Silke. 2008. "Anti-Immigrant Attitudes in Europe: Outgroup Size and Perceived Ethnic Threat." European Sociological Review 24 (1): 53-67.

Semyonov, Moshe, and Anya Glikman. 2009. "Ethnic Residential Segregation, Social Contacts, and Anti-minority Attitudes in European Societies.” European Sociological Review 25 (6): 693-708.

Shaw, Stanford J., and Ezel Kural Shaw. 1977. Reform, Revolution, and Republic Modern Turkey, 1808-1975, Vol. II of History of the Ottoman Empire and Modern Turkey. Cambridge: Cambridge University Press.

Suciyan, Talin, 2018. Modern Türiye'de Ermeniler-Soykırım Sonrası Toplum, Siyaset ve Tarih. Place: Aras Yayıncılık.

Şimşek, Yurdagul, and Ayfer Selamoğlu. 2002. "DYP'de Yeni Dönem.” Publication, December 15, 2002. http://www.radikal. com.tr/politika/dypde-yeni-donem-654462/ (Accessed October 18, 2020.)

Tashakkori, Abbas. and Charles Teddlie. 1998. Mixed Methodology: Combining Qualitative and Quantitative Approaches. Thousand Oaks: Sage Publications.

Toktas, Şule. 2005. "Citizenship and Minorities: A Historical Overview of Turkey’s Jewish Minority.” Journal of Historical Sociology 18 (4): 394-429. 
Üngör, Ugur. 2011. The Making of Modern Turkey: Nation and State in Eastern Anatolia, 1913-1950. Oxford, UK: Oxford University Press.

Ünlü, Barış. 2014. “Türklük Sözleşmesi’nin İmzalanış1 (1915-1925).” Mülkiye Dergisi 38 (3): 47-81.

Woodrum, Eric. 1984. "Mainstreaming Content Analysis in Social Science: Methodological Advantages, Obstacles, and Solutions.” Social Science Research 13 (1): 1-19.

Yavuz, Hakan. 2011. “Contours of Scholarship on Armenian-Turkish Relations.” Middle East Critique 20 (3): 231-251.

Zürcher, Erik-Jan. 2011. "Renewal and Silence: Postwar Unionist and Kemalist Rhetoric on the Armenian Genocide." In A Question of Genocide, edited by R. Suny, F. Göçek, and N. Naimark, 306-316. Oxford, UK: Oxford University Press. Zürcher, Erik-Jan. 2004. Turkey: A Modern History. New York: I.B. Tauris.

Cite this article: Nefes, T. S. 2022. The Relationship between Perceived Security Threats and Negative Descriptions of Armenians in Turkish Politics (1946-1960). Nationalities Papers 50: 1217-1231, doi:10.1017/nps.2021.6 